\title{
TEKS VERBAL DAN VISUAL MEDIA KAMPANYE PILGUB BALI
}

\author{
I Gusti Ngurah Parthama \\ Program Studi Sastra Inggris, Fakultas Ilmu Budaya, Universitas Udayana \\ Jl. Pulau Nias no. 13, 80113, Telp. (+62361) 257415 \\ ngurah_parthama@unud.ac.id
}

\begin{abstract}
ABSTRAK
Artikel ini bertujuan untuk mendeskripsikan teks verbal dan visual yang digunakan oleh kandidat gubernur ketika pemilihan gubernur (pilgub) Bali lalu. Sebagian suatu bentuk komunikasi, teks verbal dan visual pada media kampanye pilgub Bali tentunya mengandung makna dan pesan tertentu. Hal tersebut tidak lepas dari perencaan dan pembuatan suatu media kampanye yang serupa dengan media iklan. Media seperti itu mempunyai pesan dan makna tertentu yang disampaikan kepada para pembaca atau yang melihatnya. Apalagi media kampanye yang bertujuan untuk menyampaikan gagasan, pandangan, serta mengajak seseorang untuk memilih, sudah tentu memiliki pesan dan makna khusus. Sumber data yang digunakan pada artikel ini adalah media kampanye luar ruang selama pelaksanaan masa sosialisasi dan masa kampanye pilgub Bali. Sumber data diambil dari media kampanye kedua kandidat gubernur Bali yang dipasang di seluruh kabupatan/kota di Bali. Data yang digunakan adalan teks verbal dan teks visual pada media media tersebut. Hanya tiga data yang dianalisa untuk artikel ini. Metode dokumentasi diaplikasikan untuk pengumpulan data dengan teknik perekaman, pembacaan secara rinci, pemilahan, dan pengklasifikasian. Sedangkan metode deskriptif kualitatif digunakan untuk menganalisa data berdasarkan teori - teori kajian wacana. Simpulan yang diperoleh adalah teks verbal atau teks tulis media kampanye berisikan paparan informasi dan gagasan. Selain itu, pilihan kosakata mengacu pada bentuk pencitraan diri kandidat gubernur. Pada kesempatan yang sama, daya ilokusi yang dimunculkan lebih dominan pada model asertif. Sementara itu, teks visual mempunyai kecenderungan pemilihan pewarnaan, gambar kandidat, maupun logo - logo seperti partai politik tetap memberikan kontribusi pada keberlangsungan komunikasi melalui media kampanye.
\end{abstract}

Kata kunci: teks verbal, teks visual, media kampanye, pilgub Bali

\section{PENDAHULUAN}

Dalam sebuah komunikasi, pemahaman mengenai teks menjadi sangat penting. Teks berperan menjadi bagian penting dalam menyampaikan suatu pandangan, pendapat, dan berbagai model komunikasi. Sehingga teks tidak semata - mata hanya dipahami dalam bentuk verbal atau tertulis semata. Teks juga dapat berupa pemahaman terhadap gambar atau visual. Teks tulis tentunya mempunyai kekuarangan maupun kelebihan dibandingkan teks visual atau gambar. Kedua teks memiliki spesifikasi tersendiri dan pada akhirnya dapat saling menunjang pemahaman terhadap suatu konteks pemahaman yang lebih luas. Untuk itulah teks tidak dapat dilepaskan dari konteks maupun kondisi suatu masyarakat.

Media kampanye tidak lepas dari pengaruh teks verbal dan teks visual. Keduanya berperan penting dalam menyampaikan pesan kepada pembaca. Penggunaan kombinasi kedua teks sesungguhnya merupakan hal yang lumrah dilakukan. Dalam hal ini, teks media kampanye dapat dikategorikan sebagai bagian dari bentuk promosi. Yang membedakan hanyalah pada sesuatu yang dipromosikan. Jika pada media promosi, umumnya yang dipromosikan adalah barang maupun jasa. Namun, pada media kampanye yang menjadi titik fokus promosi adalah orang atau kandidat tertentu. Dalam hal ini seseorang dapat mempromosikan dirinya sebagai calon kepala negara, kepala daerah, kepala desa, anggota legislatif, maupun lainnya. Pada titik promosi seperti itulah teks verbal dan teks visual menjadi media yang menjembatani kandidat dengan para pemilihnya.

Dalam kaitannya sebagai media promosi, media kampanye luar ruang menjadi efektif saat penyampaiannya menggabungkan dua teks, teks verbal dan teks visual. Hal tersebut juga mempunyai keterikatan yang erat dengan intensitas waktu. Harus dimaklumi bahwa media kampanye luar ruang merupakan media yang ditempatkan atau diposisikan pada ruang - ruang publik. Ruang - ruang publik itu seperti jalan, perempatan jalan, lokasi strategis tertentu, maupun lokasi - lokasi lain yang dianggap efektif untuk menempatkan 
media - media tersebut. Selain penempatan pada ruang publik, yang turut menjadi pertimbangan adalah waktu. Seorang pembaca hanya memiliki waktu yang sangat terbatas ketika memperoleh informasi dari media kampanye luar ruang. Seorang pembaca hanya sekilas memperhatikan gambar serta kata - kata tertentu. Hal itu tentunya berkaitan dengan kapasitas mereka sebagai pengendara atau seseorang yang kebetulan melewati tempat tertentu.

Untuk itulah media kampanye luar ruang pada pemilihan gubernur (pilgub) Bali menjadi menarik untuk dapat dianalisa. Media kampanye yang efektif memberikan kesempatan bagi pembaca untuk mendapatkan informasi. Informasi yang dimaksud tentunya bersifat singkat, padat, dan ringkas dengan dipadukan berbagai gambar serta warna yang menarik perhatian pembaca.

\section{TINJAUAN PUSTAKA DAN LANDASAN TEORI}

Pembahasan mengenai teks verbal dan teks visual pada media kampanye tidak lepas dari sejumlah literatur yang berkaitan dengan kajian wacana. Literatur - literatur tersebut memberikan dasar untuk penelitian ini. Masing - masing dari literatur - literatur dibahas secara mendetail seperti di bawah ini.

Wijana dan Rohmadi (2009: 302) dalam Implikatur Dalam Wacana Kampanye Politik Pemilu 2009 menjelaskan bahwa bahasa verbal dan visual memiliki keterkaitan dalam memahami sebuah iklan kampanye para calon legislatif (caleg) tahun 2009. Bahasa yang dipergunakan memiliki sifat - sifat implikatur yang mudah dipahami. Namun, dalam sejumlah kasus juga menunjukkan bahwa kalimat atau kata yang dipergunakan memunculkan interpretasi atau penafsiran berbeda. Hal itu tentu saja sesuai dengan karakteristik bahasa dan budaya dimana bahasa sesungguhnya implementasi dari budaya yang dimiliki oleh suatu kelompok masyarakat. Pemahaman oleh suatu kelompok masyarakat tentunya tidak sama dengan kelompok - kelompok masyarakat yang lain. Sedangkan gambar yang ditampilkan pada iklan kampanye dengan ukuran dan karakter tertentu memberikan tambahan pemahaman terhadap suatu iklan kampanye. Secara umum dapat digambarkan oleh Wijana dan Rohmadi (2009: 302) bahwa karakteristik gambar dan bahasa yang terdapat pada baliho dan spanduk kampanye merupakan upaya untuk menarik perhatian pemilih. Upaya menarik perhatian tersebut dapat dilakukan dengan pemilihan bahasa dan kata, penempatan gambar, ikon, dan lainnya, program kerja, hadiah, maupun janji - janji terhadap para pemilihnya.

Pemahaman terhadap suatu media kampanye memang tidak dapat dilepaskan pada pemahaman terhadap wacana atau discourse. Wacana secara umum menurut Nunan (1993: 7) adalah wacana sebagai pemahaman atau penafsiran terhadap suatu peristiwa komunikasi yang berlangsung dalam suatu konteks. Sesungguhnya wacana memiliki prinsip paling dasar pada pemahamannya yaitu sebagai bahasa dalam pemakaiannya atau language in use. Sehingga apabila suatu bahasa digunakan secara tepat dengan konteks yang sesuai maka suatu komunikasi dapat berlangsung dengan baik. Untuk itulah media kampanye luar ruang merupakan suatu bentuk wacana. Melalui media kampanye luar ruang maka seorang cagub sesungguhnya sedang melakukan sebuah komunikasi dengan masyarakat sebagai calon pemilihnya. Dalam hal ini para caleg menggunakan bahasa yang telah diolah sedemikian rupa sehingga dapat dipahami oleh masyarakat umum dari berbagai kalangan. Pengolahan bahasa dan penyampaiannya tentu saja menjadi bagian dari pencitraan diri, propaganda, janji, dan persuasi. Begitu juga dengan penempatan gambar atau visual yang secara langsung mendukung maksud atau pesan dari bahasa verbal yang digunakan. Dengan demikian maka wacana dalam media kampanye luar ruang merupakan suatu bentuk kombinasi antara bahasa verbal dengan slogan dan jargon serta ditambah dengan pemanfaatan gambar atau visual untuk mendukung suatu komunikasi berupa iklan kampanye yang efektif dan efisien.

Untuk itulah secara verbal dalam media kampanye luar ruang para cagub di Bali dapat dilihat melalui mekanisme kajian tindak tutur. Dengan kajian tindak tutur yang sesuai maka dapat diperoleh penafsiran yang sesuai dan memadai terhadap bahasa verbal yang ada. Searle (dalam Wijana dan Rohmadi, 2009: 20) membagi kajian tindak tutur menjadi tiga yaitu tindak lokusi, tindak ilokusi, dan tindak perlokusi. Tindak lokusi dapat dimaknai sebagai ujaran atau tuturan semata. Dalam hal ini tindak lokusi biasanya dimaknai sebagai the act of saying something atau hanya mengujarkan saja tanpa memiliki maksud tertentu. Sehingga secara tindak tutur Parker (dalam Wijana dan Rohmadi, 2009: 21) mengatakan jika kajian 
tindak lokusi justru tidak memiliki peranan penting.

Secara lebih mendetail, Searle (dalam Leech, 1983: 327) membagi daya atau efek (illocutionary force) suatu tindak tutur ilokusi. Tindak ilokusi tidak hanya semata - mata sebagai tindak tutur yang memiliki daya atau efek pada pendengarnya. Namun tindak tutur ilokusi justru memiliki daya atau efek yang bervariasi terhadap penutur lainnya. Terdapat lima kategori dalam hal tindak tutur ilokusi menurut Searle yaitu representatif atau asertif, direktif, ekspresif, komisif, dan deklaratif. Representatif atau asertif lebih menekankan pada kebenaran yang disampaikan melalui suatu tindak tutur yang mengikat penuturnya dan hal itu tercermin dari penggunaan kata - kata seperti menyatakan, melaporkan, menunjukkan, dan menyebutkan. Sedangkan direktif lebih mengkhusus pada tindak tutur yang berhubungan dengan tindakan dan kata - kata yang mewakilinya antara lain menyuruh, memohon, menyarankan, dan menantang. Ekspresif adalah bentuk tindak tutur evaluatif terhadap hal - hal disebutkan dalam ujaran dan bentuk evaluatif tersebut tercermin melalui kata kata memuji, mengkritik, dan mengeluhkan. Sementara kategori komisif lebih memfokuskan pada pelaksanaan terhadap apa yang telah disebutkan dalam suatu ujaran dan hal itu terwakili melalui kata - kata mengancam, berjanji, dan bersumpah. Kategori berikutnya adalah deklaratif yang cenderung menekankan pada penciptaan sesuatu yang baru melalui tuturannya dan tuturan deklaratif tercermin melalui kata - kata memutuskan, membatalkan, dan mengizinkan.

Sedangkan secara bahasa nonverbal atau visual, Dyer (1993: 97) memaparkan tiga elemen penting untuk mengkajinya. Ketiga elemen tersebut adalah tampilan (appearance), sikap (manner), dan aktivitas atau kegiatan (activity). Lebih lanjut Dyer membagi ketiga elemen itu ke dalam faktor - faktor yang lebih rinci. Perincian tersebut untuk mengkaji secara lebih mendalam dan mendetail bahasa nonverbal atau visual suatu media iklan. Elemen tampilan (appearance) dibagi lagi menjadi faktor - faktor detail seperti usia (age), gender, kewarganegaraan dan etnis (nationality and racial), rambut (hair), tubuh (body), ukuran (size), dan penampilan (looks). Sementara itu elemen sikap (manner) dibagi menjadi sejumlah faktor seperti ekspresi (expression), kontak mata (eye contact), posisi (pose), dan pakaian (clothes). Elemen berikutnya adalah kegiatan atau aktivitas (activity) dengan faktor - faktor perincinya antara lain sentuhan (touch), gerakan tubuh (body movement), dan posisi dalam komunikasi (positional communication). Selain itu Dyer (1993: 105) juga menambahkan elemen pendukung yang juga penting dalam mengkaji bahasa nonverbal seperti props dan setting. Props merupakan kesesuaian antara produk dengan lingkungan sekelilingnya terutamanya yang berkaitan dengan produk tersebut. Sedangkan setting lebih mengacu pada latar belakang yang biasanya berkaitan dengan orang atau barang pada sebuah gambar.

Mahayani (2009) dalam artikelnya yang berhubungan dengan bahasa verbal dan bahasa nonverbal iklan layanan masyarakat lebih menyoroti pada penggunaan gambar atau visual dengan tiga macam jenis ikon berdasarkan Pierce (dalam Willem dan Cuypere, 2008). Pierce seperti dikutip Mahayani membagi ikon pada iklan menjadi tiga yaitu imagik, diagramatik, dan metaforik. Imagik yaitu ikon yang penandanya menyerupai realitas yang diacu seperti misalnya gambar pohon untuk mendukung iklan kegiatan penghijauan atau pelestarian hutan. Diagramatik adalah ikon yang memiliki struktur geometris dengan apa yang diwakilinya dan didasarkan pada hubungan antara tanda yang mencerminkan kemiripan obyek atau tindakan. Terakhir adalah metaforik yang lebih menekankan pada ikon yang metatanda (metasign) yang berdasarkan kemiripan di antara obyek dari dua tanda simbolis. Sehingga ikon metaforik merupakan ikon yang penandanya mengacu pada beberapa referen yang mempunyai kemiripan. Lebih lanjut Mahayani menemukan bahwa dalam iklan layanan masyarakat kecenderungan bahasa nonverbal atau visual yang digunakan adalah ikon imajik dan ikon metaforik. Penggunaan kedua ikon lebih sering untuk saling mendukung dan saling melengkapi antara bahasa verbal dan bahasa nonverbal. Dengan adanya gambar atau ikon tertentu maka masyarakat dapat dengan mudah memahami maksud pesan dari suatu bahasa verbal.

\section{METODE PENELITIAN}

Sumber data yang digunakan pada penelitian ini adalah media kampanye luar ruang selama masa kampanye pemilihan gubernur (pilgub) Bali tahun 2018. Sedangkan data yang digunakan adalah teks verbal dan teks visual yang terdapat pada media kampanye luar ruang. Media 
kampanye luar ruang yang digunakan adalah baliho dan spanduk. Metode yang digunakan pada pengumpulan data penelitian ini adalah metode dokumentasi. Metode dokumentasi ditunjang dengan sejumlah teknik untuk memperoleh data yang komprehensif. Adapun teknik - teknik yang diaplikasikan antara lain teknik perekaman data berupa pemotretan media kampanye luar ruang. Data yang berkaitan dengan media kampanye berupa baliho dan spanduk direkam dengan kamera. Selanjutnya teknik pemilahan dalam hal ini digunakan untuk memastikan data yang sesuai untuk dianalisa lebih lanjut. Berikutnya teknik mencatat yang berkaitan dengan teks verbal maupun teks visual yang terdapat pada data. Pencatatan yang paling dominan terdapat pada pencatatan teks verbal pada media kampanye. Metode yang digunakan pada analisa data adalah metode deskriptif kualitatif. Metode deskriptif kualitatif merupakan metode yang memaparkan atau mendeskripsikan suatu data secara kualitatif berdasarkan teori - teori terkait. Dalam hal ini, penelitian ini akan mengaplikasikan analisa deskriptif kualitatif terhadap data berdasarkan konsep teori daya (force) pada teks verbal dan konsep teori yang berhubungan dengan teks visual.

\section{HASIL DAN PEMBAHASAN}

Tiga data media kampanye pilgub Bali dianalisa pada bagian ini. Ketiga data sesungguhnya mempresentasikan masing - masing kandidat saat pelaksanaan pilgub Bali. Data media kampanye pertama merupakan media kampanye bersama kedua kandidat. Media kampanye tersebut merupakan media kampanye resmi yang diletakkan di lokasi - lokasi strategis. Sedangkan dua media kampanye lainnya, merepresentasikan masing masing kandidat, adalah media kampanye saat masa sosialisasi. Dimana ketika itu seseorang atau kelompok masyarakat menginformasikan dalam bentuk media serupa media kampanye kandidat yang menjadi pilihannya. Masing - masing data dibahas secara lebih terinci dalam hal verbal dan visual di bawah ini.

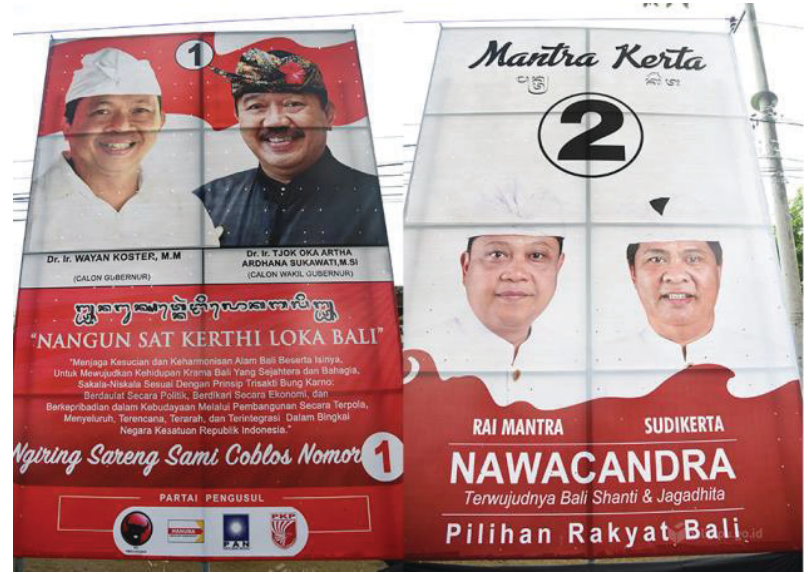

\section{DATA 1}

Data $1 \mathrm{di}$ atas terdiri dari dua baliho media kampanye luar ruang cagub Bali. Kedua data merupakan media kampanye luar ruang yang resmi digunakan oleh pihak tim sukses masing - masing calon kandidat dan Komisi Pemilihan Umum (KPU) Bali di seluruh wilayah kabupaten/kota. Artinya, data 1 adalah media kampanye resmi yang digunakan di seluruh wilayah Bali dalam kaitannya dengan pemilihan kepala daerah (pilkada) Bali 2018. Setiap baliho di data 1 memiliki teks verbal dan teks visual dalam menyampaikan informasinya.

Penjelasan data 1 dibedakan menjadi dua bagian yang terdiri dari data kiri dan data kanan. Data kiri adalah data kandidat cagub dengan nomor urutan 1 dan data kanan merupakan data kandidat cagub dengan nomor urutan 2. Dalam kajian teks visual, kedua baliho pada data 1 memperlihatkan kandidat dengan menggunakan pakaian adat Bali. Yang membedakan hanya pada warna pakaian yang dikenakan. Pada baliho kiri, kandidat cagub dan cawagub mengenakan pakaian adat Bali berwarna putih dan hitam. Sementara pada baliho kanan kedua kandidat menggunakan pakaian adat Bali berwarna putih. Secara teks visual, kedua baliho menunjukkan kandidat yang sedang tersenyum. Sedangkan warna dominan pada baliho data 1 adalah merah dan putih. Ada pun baliho sebelah kiri memiliki proporsi warna merah dan putih yang seimbang. Selain itu, kandidat pada baliho kiri juga dilatarbelakangi dengan bendera Republik Indonesia, merah putih. Sementara pada baliho sebelah kanan di data 1 didominasi warna putih dan warna merah pada bagian bawah.

Secara pemaknaan, pilihan kandidat cagub dan cawagub pada data 1 menunjukkan adanya kedekatan pada budaya Bali. Hal ini berkaitan 
dengan pilkada yang akan digelar adalah pilkada Propinsi Bali. Sehingga identitas yang melekat pada masing - masing kandidat memperlihatkan representasi budaya Bali. Yang menarik justru pada pemilihan warna pakaian adat Bali di baliho sisi kiri (kandidat nomor 1). Pemilihan warna putih dan hitam pada pakaian cagub dan cawagub adalah bentuk pemaknaan budaya Bali yang dikenal dengan rwa bhineda. Konsep budaya rwa bhineda mengacu pada dua sisi yang selalu ada dalam kehidupan manusia di dunia baik itu lahir meninggal, suka - duka, untung - rugi, sehat sakit, dan lainnya. Konsep tersebut adalah konsep yang paling dikenal oleh masyarakat Bali. Sedangkan dominasi warna merah dan putih pada kedua baliho mencirikan representasi negara Republik Indonesia. Dalam hal ini lebih banyak dihubungkan dengan bendera negara RI, merah putih. Meskipun tidak secara langsung memperlihatkan dominasi warna merah dan putih, namun keberadaan warna merah dan putih mencirikan pada negara RI. Apalagi jika dihubungkan dengan keberadaan Bali yang merupakan bagian dari wilayah Indonesia. Secara sederhana, Bali adalah bagian dari negara RI. Yang justru menjadi menarik adalah kedua baliho lebih cenderung menempatkan warna putih di bagian atas dan warna merah pada sisi bagian bawah. Dengan posisi warna putih di bagian atas dan warna merah pada bagian bawah, maka dapat dipahami jika masing - masing warna memberi arti tertentu bagi kandidat itu. Warna putih merepresentasikan arti suci dan warna merah memberikan arti berani. Selain gambar kandidat dan warna putih serta merah, kedua baliho pada data 1 juga berisikan angka 1 dan 2 sebagai nomor pilihan kandidat. Data 1 juga berisikan logo - logo partai pendukung pada bagian bawah baliho. Hal itu terlihat pada baliho sisi kiri.

Pada sisi kajian verbal, data 1 di atas berisikan dua model teks tertulis. Pertama adalah teks tertulis latin dan teks tertulis menggunakan huruf Bali. Teks tertulis latin lebih dominan pada kedua baliho di data 1 . Teks verbal yang sangat lengkap juga dapat dilihat pada baliho sisi kiri. Sedangkan baliho sisi kanan pada data 1 hanya terdiri dari beberapa kata saja. Teks verbal menggunakan bahasa Bali digunakan pada slogan pada baliho sisi kiri dan teks tulisan Bali dipakai sebagai penjelas tambahan pada nama cagub dan cawagub di baliho sisi kanan.

Sekilas dapat dilihat struktur verbal kedua baliho pada data 1 berisikan tiga bagian. Ketiga bagian itu antara lain penamaan dari kandidat cagub dan cawagub, slogan dari setiap kandidat, dan terakhir visi misi kandidat. Terkait visi misi kandidat, kedua baliho memperlihatkan cara yang berbeda. Baliho sisi kiri cenderung mendeskripsikan keseluruhan informasi visi misinya dan baliho sisi kanan justru lebih minimalis dalam penyampaian visi misinya. Teks verbal pada baliho sisi kiri berisikan tulisan Nangun Sat Kerthi Loka Bali; menjaga kesucian dan kehamonisan alam Bali beserta isinya untuk mewujudukan kehidupan krama Bali yang sejahtera dan bahagia sekala-niskala sesuai dengan prinsip trisakti Bung Karno, berdaulat secara politik, berdikari secara ekonomi, dan berkepribadian dalam kebudayaan melalui pembangunan secara terpola, menyeluruh, terencana, terarah, dan terintegrasi dalam bingkai negara kesatuan Republik Indonesia; dan ngiring sareng sami coblos nomor 1. Sementara teks verbal pada baliho sisi kanan bertuliskan Mantra Kerta; Nawacandra terwujudnya Bali shanty \& jagadhita; dan Pilihan Rakyat Bali.

Teks verbal sisi kiri memiliki kedekatan dengan masyarakat dan budaya Bali. Hal itu tercermin dari penggunaan bahasa Bali Nangun sat kerthi loka Bali dan Ngiring sareng sami coblos nomor 1. Penggunaan nangun sat kerthi loka Bali merupakan slogan dari kandidat pertama. Sementara itu, model persuasif atau ajakan dimunculkan pada bagian akhir baliho dengan bahasa Bali ngiring sareng sami coblos nomor 1 . Pemakaian bahasa Bali alus ngiring sareng sami coblos nomor 1 menjadi suatu bentuk penghargaan terhadap para pemilih. Hal itu dikarenakan pemilih mempunyai hak suara untuk memenangkan seorang kandidat atau figur dalam pilkada. Sehingga pemilihan bahasa Bali alus bertujuan untuk penghargaan atau penghormatan kepada mereka. Selain itu, penggunaan bahasa daerah dalam media kampanye memiliki fungsi untuk mendekatkan kandidat dengan para pemilihnya. Mereka dapat merasakan kesamaan dengan penggunaan bahasa maupun budaya yang sama. Sedangkan penjelasan visi - misi pada baliho kiri sudah sangat jelas. Deskripsi visi - misi sudah mencakup keseluruhan model pembangunan yang akan dilaksanakan dan seiring dengan pembangunan negara RI.

Teks verbal pada baliho sisi kanan di data 1 lebih banyak menggunakan bahasa nasional, bahasa Indonesia, dalam mengkomunikasikan visi misinya. Penggunaan bahasa Bali hanya digunakan 
pada slogan Mantra Kerta yang ditempatkan pada bagian atas baliho. Itu pun sesungguhnya merupakan pemilahan nama dari kandidat cagub dan cawagub yang secara langsung dipakai sebagai slogan kandidat nomor 2. Jika diartikan secara latin, mantra berarti doa dan kerta berarti kesejahteraan. Hampir sama seperti kandidat nomor 1, kandidat nomor 2 juga menekankan visi misi pada kesejahteraan masyarakat Bali. Selanjutnya visi misi pada baliho nomor dua ditulis dengan Nawacandra terwujudnya Bali shanti \& jagadhita yang artinya program - program yang bertujuan mewujudkan kedamaian dan kebahagiaan bagi Bali. Sedangkan teks verbal dengan model persuasif yang muncul adalah pilihan rakyat Bali. Model persuasif yang digunakan tidak menekankan ajakan, namun lebih pada bentuk pencitraan. Untuk itu, pemilihan frasa pilihan rakyat Bali menunjukkan pada kepastian pilihan rakyat Bali pada pilkada Bali mendatang.

Apabila memperhatikan model teks verbal pada kedua baliho di data 1 , maka dapat dilihat jika pemuatan informasi berbeda. Visi misi yang dideskripsikan secara menyeluruh dapat dilihat pada baliho sisi kiri dan deskripsi sederhana dapat dilihat pada baliho sisi kanan. Penggunaan bentuk persuasif dengan model tindak tutur direktif atau ajakan lebih terlihat pada baliho sisi kiri dengan penggunaan bahasa Bali ngiring sareng sami coblos nomor 1. Sedangkan bentuk persuasif dengan kecenderungan pencitraan muncul pada baliho sisi kanan dengan tulisan pilihan rakyat Bali. Kedua baliho juga menggunakan pendekatan pada bahasa dan budaya Bali. Hal itu dapat dilihat dengan penggunaan tulisan Bali dan pemakaian bahasa Bali latin pada kedua baliho kandidat cagub Bali 2018. Dari sisi daya ilokusi teks verbal yang terdapat pada keduanya lebih cenderung diklasifikasikan kepada model asertif. Model asertif menunjukkan ujaran yang mengikat penuturnya. Jika diperhatikan teks tulis pada kedua media kampanye pilgub, maka keduanya menunjukkan sesuatu yang dikerjakan jika terpilih. Penunjukan atau penyebuatan hal - hal yang akan dilakukan ketika terpilih sebagai gubernur merupakan ciri khas asertif dalam daya ilokusi suatu tuturan.

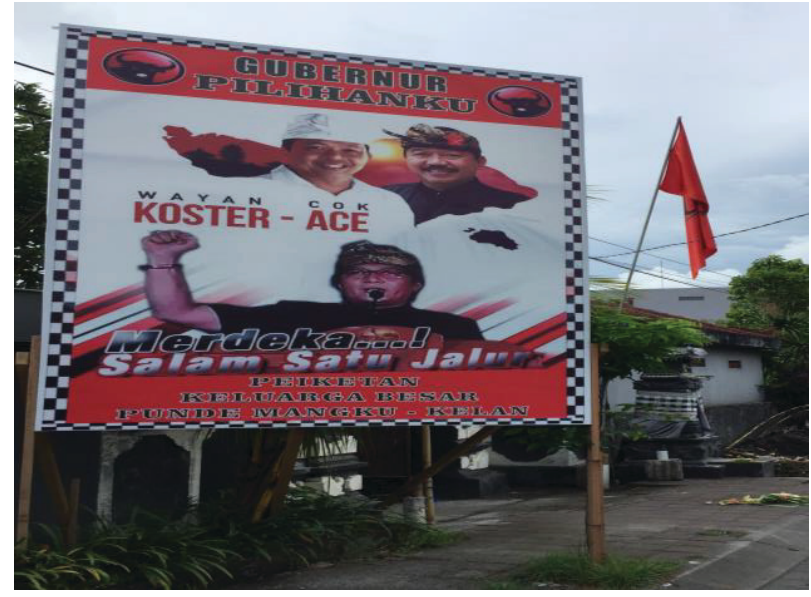

DATA 2

Media kampanye luar ruang pada data 2 juga terdiri dari kombinasi teks verbal dan teks visual. Data 2 merupakan salah satu dari media kampanye sosialisasi cagub dan cawagub Bali 2018. Teks visual pada data 2 terdiri dari gambar dan pewarnaan. Gambar mencakup figur kandidat cagub-cawagub dan ketua tim sukses, gambar logo partai pendukung, dan pewarnaan dalam tiga jenis yaitu merah, putih, dan hitam-putih. Sedangkan teks verbal berisikan tulisan - tulisan berupa gubernur pilihanku; nama cagub-cawagub; merdeka...! Salam satu jalur; dan identitas masyarakat pemasang baliho.

Teks visual secara rinci terdiri dari gambar kandidat cagub - cawagub serta gambar ketua tim sukses dan logo partai. Gambar logo partai sudah menunjukkan kejelasan makna yaitu sebagai partai pendukung. Pada gambar dapat dilihat jika ketua tim sukses menggunakan pakaian adat Bali dengan foto mengepalkan tangan kanan. Kepalan tangan secara harfiah dapat dimaknai sebagai bentuk penyemangat. Dalam hal ini menyemangati para calon pemilih untuk memilih calon yang diusung. Selain itu, kepalan tangan juga dapat diartikan sebagai wujud kekuatan. Dalam hal ini wujud kekuatan yang dimaksudkan tentunya wujud kekuatan untuk dapat memenangkan kompetisi pilkada. Gambar kandidat cagub dan cawagub juga dilatarbelakangi gambar pulau Bali. Gambar tersebut memberikan arti bahwa mereka merupakan calon pemimpin Bali. Sementara warna merah dan putih serta hitam-putih (dalam bahasa Bali disebut poleng) memiliki arti tersendiri. Warna merah memperlihatkan keberanian, warna putih menunjukkan kesucian, dan warna hitamputih (poleng) mencerminkan dua sisi kehidupan yang selalu ada pada diri seseorang. Keberanian 
dan kesucian tentunya menjadi dasar bagi kepemimpinan kandidat yang dimaksud. Sedangkan pilihan warna hitam-putih pada bagian luar baliho menjadi bingkai atau menjadi batas bagi seorang pemimpin.

Sementara itu, teks verbal berisikan tulisan gubernur pilihanku dan merdeka...! salam satu jalur. Frasa gubernur pilihanku ditempatkan pada bagian atas sebagai penarik perhatian. Frasa tersebut tentu saja dengan mudah menarik perhatian publik atau calon pemilih yang melihat baliho itu. Selain menarik perhatian, penggunaan frasa gubernur pilihanku juga diartikan sebagai bentuk pencitraan dan penegasan. Pencitraan dapat dilihat pada penggunaan kata pilihan dan penegasan pada penggunaan kata pilihanku. Dengan model pencitraan dan penegasan itu maka dapat diartikan jika seseorang atau kelompok masyarakat tertentu telah memastikan pilihan pada satu kandidat tertentu. Sedangkan penggunaan ekspresi verbal merdeka...! salam satu jalur lebih pada slogan. Slogan itu terdiri dari pekik merdeka...! dan salam satu jalur. Pemaknaan slogan merdeka adalah suatu bentuk kebebasan pilihan untuk menentukan calon yang dianggap sesuai memimpin suatu daerah. Dalam hal ini adalah daerah Bali. Sementara ekspresi verbal salam satu jalur mengacu pada kesatuan pemimpin yang berasal dari partai yang sama. Hal ini berkaitan dengan Presiden RI yang berasal dari partai yang sama dengan kandidat pada data nomor 2. Sehingga memunculkan alur atau jalur pemimpin yang berasal dari partai yang sama.

Analisa secara daya ilokusi menunjukkan teks tulis pada data 2 cenderung pada model asertif. Dalam hal ini teks yang digunakan memperlihatkan adanya suatu bentuk pernyataan seperti gubernur pilihanku. Sehingga pernyataan tersebut sejalan dengan ciri utama asertif yang mengikat penuturnya. Media kampanye itu telah memperlihatkan suatu bentuk pernyataan yang mengikat dalam suatu tuturan. Pengikatan dalam bentuk tuturan teks tulis itu dapat dilihat dengan penggunaan ujaran gubernur pilihanku.

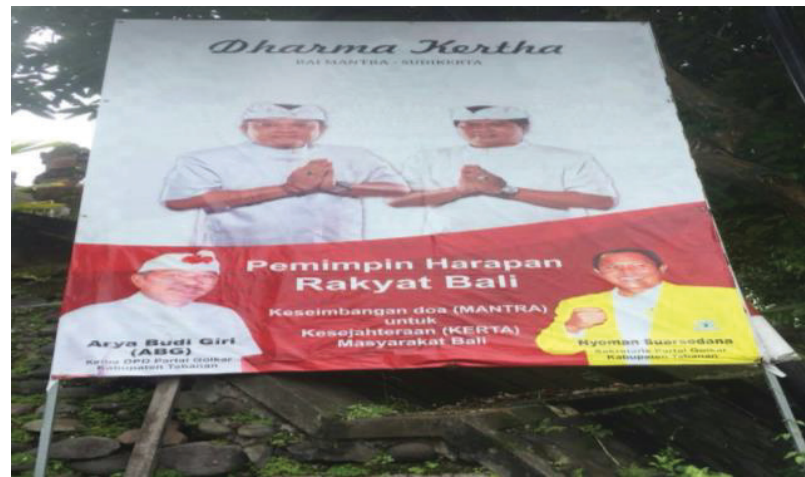

DATA 3

Data 3 berisikan teks verbal dan teks visual pada media kampanye sosialisasi luar ruang cagub Bali 2018. Data 3 memperlihatkan teks visual kandidat cagub-cawagub dengan proporsi berbeda sehingga memperlihatkan separuh posisi badan. Sedangkan dua gambar lainnya yang merupakan tokoh partai menunjukkan gambar yang sedikit berbeda. Pada bagian teks verbal, terdapat sejumlah tulisan yang berkaitan dengan sang calon. Tulisan yang ada antara lain dharma kerta; pemimpin harapan rakyat Bali; dan keseimbangan doa (mantra) untuk kesejahteraan (kerta) masyarakat Bali.

Untuk menganalisa lebih lanjut, teks visual terbagi menjadi dua yaitu gambar dan pewarnaan. Gambar yang muncul adalah gambar kandidat cagub-cawagub dan gambar tokoh partai. Pada teks visual utama yaitu gambar kandidat cagubcawagub menunjukkan posisi keduanya berdiri mengenakan pakaian adat Bali dan mencakupkan kedua tangan di dada. Secara makna dapat diartikan jika keduanya menyampaikan salam kepada seluruh calon pemilih. Dalam budaya Bali, cakupan tangan di dada dilakukan apabila seseorang bertemu atau berkunjung kepada orang lain sembari mengucapkan salam dalam agama Hindu. Cakupan tangan di dada juga dimaknai sebagai pengharapan kedamaian dan kesejahteraan terhadap orang lain dan diri sendiri. Sedangkan pada visual tokoh partai, salah satu tokoh mengepalkan tangan yang merepresentasikan sebagai bentuk semangat dan kekuatan untuk memenangkan kandidat yang didukung. Warna yang dominan adalah putih dan merah. Warna putih mempunyai makna kesucian dan warna merah berarti keberanian.

Teks verbal terdiri dari tiga bagian yaitu dharma kerta; pemimpin harapan rakyat Bali; dan keseimbangan doa (mantra) untuk kesejahteraan (kerta) masyarakat Bali. Dari ketiganya, bagian 
dharma kerta merupakan bagian awal atau penarik perhatian dari baliho data 3 . Hal itu mengingat bagian dharma kerta diambil dari cuplikan nama kandidat cagub-cawagub. Sedangkan bagian tengah yang bertulis pemimpin harapan rakyat Bali adalah model semboyan. Frasa itu berkaitan dengan bahasa pencitraan yang diperlihatkan dengan penggunaan frasa pemimpin harapan. Jika dimaknai, frasa pemimpin harapan diartikan sebagai pemimpin yang sudah ditunggu atau dinanti. Model pencitraan selanjutnya merupakan bagian dari penjelas semboyan yang bertuliskan keseimbangan doa (mantra) untuk kesejahteraan (kerta) masyarakat Bali. Pada bagian tambahan penjelas semboyan dikaitkan dengan makna dari setiap kata dari nama kandidat cagub-cawagub yang dihubungkan dengan kondisi di masyarakat. Di sini arti mantra dihubungkan dengan doa dan kata kerta diartikan sebagai kesejahteraan. Sehingga muncul keterkaitan antara slogan pemimpin harapan rakyat Bali dan penjelasnya keseimbangan doa (mantra) untuk kesejahteraan (kerta) masyarakat Bali. Selain itu, memperhatikan daya ilokusi yang menjadi model pada data 3 di atas adalah model asertif. Model asertif atau pengikatan terhadap penutur dapat dilihat dari pernyataan atau penyebutan pada bagian pemimpin harapan rakyat Bali. Teks tersebut mengacu kepada suatu pernyataan atau penyebutan salah satu kandidat sebagai calon pemimpin harapan rakyat Bali.

\section{SIMPULAN}

Memperhatikan pemaparan dari ketiga data sebelumnya maka dapat disimpulkan bahwa teks verbal dan visual mempunyai kekhususan masing - masing dan korelasi yang saling mendukung dalam sebuah komunikasi. Teks verbal pada media kampanye kandidat Gubernur Bali mempunyai makna - makna yang berkaitan dengan pencitraan diri sang kandidat, informasi terkait kandidat maupun visi misi, dan kecenderungan adanya suatu model pencitraan melalui kosakata kosakata tertentu. Dalam kaitan dengan model daya ilokusi, maka yang dominan muncul adalah daya ilokusi asertif yang lebih menekankan pada pernyataan terhadap suatu kondisi. Sedangkan secara visual, pemilihan warna, gambar kandidat, maupun logo menjadi pertimbangan yang memiliki keterkaitan dengan konteks - konteks tertentu. Pada media kampanye resmi pemilihan warna didominasi warna merah putih yang diartikan dalam konteks warna bendera Negara Indonesia. Sedangkan media kampanye saat sosialisasi kandidat cenderung didominasi warna - warna yang berasal dari partai - partai pendukung. Sehingga gambar maupun logo terutama logo partai politik juga turut menyesuaikan.

\section{DAFTAR PUSTAKA}

Dyer, Gillian. 1993. Advertising as Communication. New York: Routledge.

Koentjaraningrat. 1987. Kebudayaan Mentalitas dan Pembangunan. Jakarta: PT Gramedia.

Leech, Geoffrey. 1983. The Principles of Pragmatics. New York: Longman.

Mahayani, Ni Putu Sri. 2013. Kekuatan Bahasa Verbal dan Nonverbal Dalam Iklan Layanan Masyarakat dalam Dinamika Bahasa Media Televisi, Internet Dan Surat Kabar, editor Prof. Dr. I Wayan Pastika, M.S. Denpasar: Udayana University Press.

Nunan, David. 1993. Discourse Analysis. London: Penguin English.

Rozak, Achmad Fuad Abdul. 2009. Iklan Politik Caleg Dalam Persepsi Pemilih Pemula. Skripsi. Surakarta: Universitas Sebelas Maret. Diunduh pada tanggal 18 Februari 2014.

Wijana, I Dewa Putu dan Muhammad Rohmadi. 2009. Analisis Wacana Pragmatik Kajian Teori dan Analisis. Surakarta: Yuma Pustaka. 